\title{
Comparison of proliferation rates assessed using "multiblock" and conventional tissue blocks of lung carcinoma
}

\author{
D C Brown, K C Gatter
}

\begin{abstract}
Aims: To compare the proliferative rates, assessed immunohistochemically, of human lung tumours using conventional paraffin wax blocks and the multitumour tissue block (MTTB) technique.

Methods: A multiblock containing 20 lung tumours (eight adenocarcinomas, five squamous cell, five small cell and two carcinoid tumours) was constructed. Sections were also cut from the original blocks of formalin fixed, paraffin wax embedded tissue used to construct the multiblock. Sections were stained with the monoclonal antibody PC10, which recognises a proliferating cell nuclear antigen, using the three stage immunoperoxidase technique.

Results: The proliferation rates of the lung tumours obtained using both techniques were, overall, significantly different $(p=$ 0.05 ), although most cases showed good correlation. Some tumours displayed a high degree of intratumoral variation in PC10 staining. The degree of PC10 staining was in keeping with the known proliferative state of particular histological subtypes-that is, carcinoid tumours showed little staining and small cell carcinomas showed extensive positivity.

Conclusion: The MTTB technique is a less suitable means of assessing proliferation rate in lung carcinomas than conventional tissue blocks. It should be restricted to qualitative antibody studies or quantitative studies using tumours with little intratumoral variation.
\end{abstract}

Many monoclonal antibodies are now available to diagnostic pathologists. Each antibody requires extensive biochemical and immunohistochemical characterisation before it can be considered for diagnostic purposes. This involves screening the antibody on a large number of normal and pathological tissues, a process which is time consuming and often tedious for the screening pathologist. In 1986 Battifora described a technique, ${ }^{1}$ which has subsequently been modified and refined, ${ }^{23}$ which allows a large number of tissues to be examined rapidly. This involves the embedding of up to 100 different tissue samples in a normal sized paraffin wax block to create what is known as a multitumour tissue block (MTTB). One of the authors (KCG) has used a modified version of this technique and found it useful in qualitative immunohistochemical studies involving new antibodies. ${ }^{4}$

Recently a monoclonal antibody, PC10, has become available which identifies a proliferating cell nuclear antigen (PCNA). This antibody can be used to assess the proliferation rate of tumours in routine material and therefore provides information that may be of value in clinical practice for predicting tumour behaviour. ${ }^{5}$ Studies involving PC10 differ from other immunohistochemical studies in that quantitative observations are made by counting positively stained tumour cell nuclei. The use of the MTTB technique in tumour proliferation studies would be advantageous because it offers an economical and convenient means of investigating the large number of cases required for prognostic studies. However, it is not known whether the results obtained from such a quantitative investigation will be valid, as one of the major criticisms directed against the assessment of tumour proliferation by immunohistochemical means has been that of inadequate sample size. ${ }^{6}$

The aim of this study is to determine whether the estimates of tumour proliferation obtained from tissues within an MTTB differ significantly from the estimates obtained using the original conventional tissue block of the same tumours. If the values between the two groups are not significantly different then the MTTB technique may offer a preferable means of assessing the proliferation rates of large numbers of tumours.

\section{Methods}

A multitumour tissue block was constructed from 20 cases of lung carcinoma (eight adenocarcinoma, five squamous cell, five small cell and two carcinoid tumours). Each core of tissue measured about $4 \mathrm{~mm}$ in diameter $(12.5$ $\mathrm{mm}^{2}$ ) and was obtained from a conventional sized paraffin wax block of the tumour by means of a disposable skin punch biopsy instrument.

The original blocks of formalin fixed and paraffin wax embedded tissue, from which the MTTB components were obtained, provided sections of tumour about $15 \times 25 \mathrm{~mm}(375$ $\mathrm{mm}^{2}$ ). These blocks of tissue were taken from the most viable-that is, the least necrotic areas of the tumour as assessed macroscopically. In large tumours with necrotic centres this involved sampling of the tumour's periphery. The tumours were typed histologically using haematoxylin and eosin stained sections using currently accepted diagnostic criteria. ${ }^{7}$

The sections were stained using a three stage 
Table 1 Comparison of proliferative indices of 20 lung carcinomas, using multi tumour tissue block technique and conventional tissue blocks

\begin{tabular}{llll}
\hline $\begin{array}{l}\text { Case } \\
\text { No }\end{array}$ & Type & $\begin{array}{l}\text { Multiblock } \\
(\%)\end{array}$ & $\begin{array}{l}\text { Conventional } \\
\text { block } \\
(\%)\end{array}$ \\
\hline 1 & Small cell & 62 & 45 \\
2 & Carcinoid & 3 & $<1$ \\
3 & Carcinoid & $<1$ & $<1$ \\
4 & Small cell & 53 & $44 \cdot 5$ \\
5 & Small cell & 39 & $35 \cdot 7$ \\
6 & Small cell & 79 & 49 \\
7 & Small cell & 9 & 24 \\
8 & Adenocarcinoma & 46 & 46 \\
9 & Adenocarcinoma & 18 & $8 \cdot 8$ \\
10 & Adenocarcinoma & $3 \cdot 3$ & $2 \cdot 1$ \\
11 & Adenocarcinoma & 41 & $11 \cdot 5$ \\
12 & Adenocarcinoma & 11 & 3 \\
13 & Squamous cell & 29 & $16 \cdot 7$ \\
14 & Adenocarcinoma & $35 \cdot 2$ & 45 \\
15 & Adenocarcinoma & $16 \cdot 1$ & 30 \\
16 & Adenocarcinoma & $18 \cdot 6$ & $17 \cdot 6$ \\
17 & Squamous cell & 40 & $55 \cdot 9$ \\
18 & Squamous cell & $40 \cdot 2$ & $39 \cdot 9$ \\
19 & Squamous cell & $46 \cdot 7$ & 26 \\
20 & Squamous cell & $47 \cdot 7$ & $34 \cdot 6$ \\
\hline Wilcoxon & matched pairs, signed & ranks test & $=0.05$
\end{tabular}

immunoperoxidase technique. ${ }^{8}$ The monoclonal antibody, PC10 is obtainable from Dako.

One thousand tumour cells were counted in randomly selected areas of viable tumour (necrotic regions and areas with a pronounced stromal component were excluded). The number of positive cells was expressed as a percentage of the total number of cells counted (the proliferation index or PI). Although increasing the sample size from 500 cells per case to 1000 cells did not change the PI result, the latter number was used to be certain of obtaining a representative count for a particular tissue section. In a few cases, using the MTTB specimens, this number (1000) approached the actual number of viable tumour cells available for counting in the tissue sample.

The Wilcoxon matched pairs signed ranks test for non-parametric values was used.'

\section{Results}

The proliferative indices of the 20 cases are given in table 1 . These results are displayed in histogram format to demonstrate the wide

Comparison of proliferation rates using MTTB and conventional tissue blocks

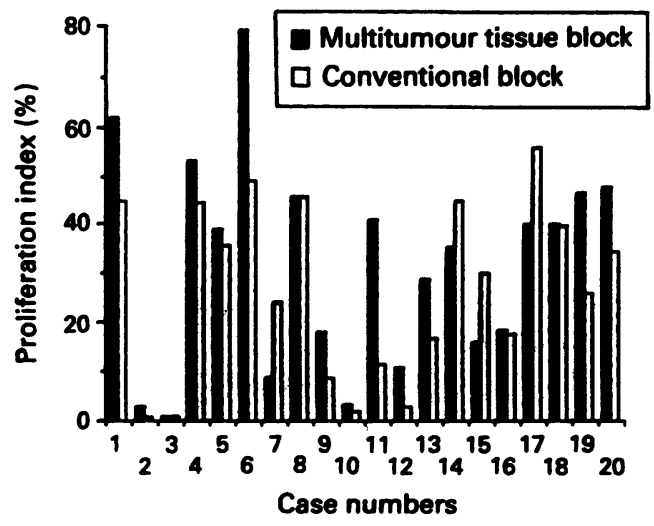

Figure 1 variation in the proliferation index seen in a few cases (fig 1).

Staining with the antibody $\mathrm{PC} 10$ produced generally strong nuclear staining except in cells which were in mitosis where the staining was cytoplasmic. Only nuclear staining was included in the cell counts. The distribution of the proliferating cells was homogenous in some cases; in others there was considerable variation within tumours. For any given case a similar pattern of distribution was seen in each of the two types of section-that is, MTTB and conventional block. In cases of squamous cell carcinoma of the lung a characteristic staining pattern was observed, with the peripheral portions of the invasive tumour islands displaying the most positivity (fig 2 ).

Table 2 shows the mean proliferative indices according to the histological subtype of the lung tumour. Carcinoid tumours showed the least number of cells staining with PC10 (fig 3) and the small cell carcinomas generally displayed the greatest number of positive cells (fig 4).

\section{Discussion}

It is generally believed that the proliferation rate of a tumour is one factor in determining clinical behaviour. ${ }^{10-14}$ Many studies have now been undertaken using monoclonal antibody $\mathrm{Ki}-67$ to assess the growth fractions of a wide range of different tumours. ${ }^{15}$ Such information has been shown to have prognostic value in certain situations. ${ }^{16-18} \mathrm{Ki}-67$ can only be used on fresh unfixed material because the $\mathrm{Ki}-67$ antigen is easily destroyed by formalin, ${ }^{19}$ and hence the prognostic studies are usually of a prospective nature. The requirement for cryostat sections does not lend itself to the multitissue tumour block technique. However, PC10 is an antibody raised against genetically engineered proliferating cell nuclear antigen (PCNA), the DNA polymerase $\delta$ accessory protein ${ }^{20}$ and identifies cells which are in the late $\mathrm{Gl}$ and $\mathrm{S}$ stages of the cell cycle. Unlike $\mathrm{Ki}-67$, it can be used on formalin fixed and paraffin wax embedded tissue, thereby opening the possibility of retrospective prognostic studies using archival material. Because a large number of cases are likely to be involved, use of the MTTB technique is attractive in terms of economy and convenience. The results of this study, however, show that although most of the cases showed excellent correlation between the two techniques (fig 1), a few showed a large discrepancy, and, overall, this difference between the two groups, reached significant levels $(p=0.05)$.

One of the major criticisms of previous immunocytochemical studies assessing tumour proliferation has been that of sampling error. ${ }^{6}$ A conventional paraffin wax block provides a tissue section with an area some 30 times that of the tissue core in a multitissue tumour block. Although the use of conventional tissue sections is still open to the criticism of sampling error, they will, presumably, more accurately reflect the overall proliferation rate of the tumour than the much smaller MTTB tissue 


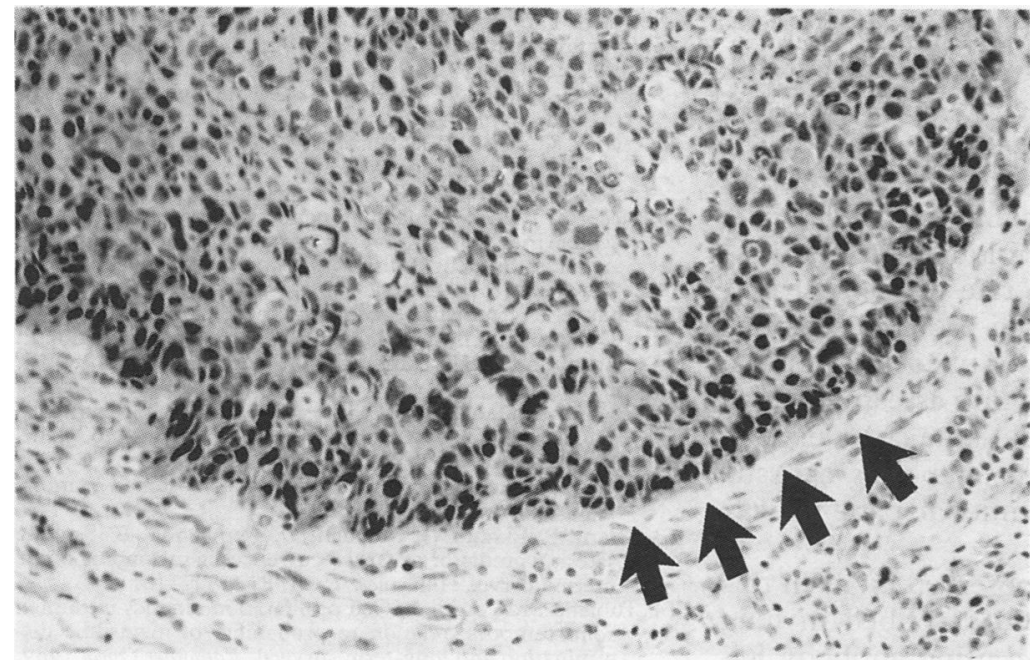

Figure 2 Section of squamous cell carcinoma of the lung stained with PC10. Maximum staining of tumour nuclei occurs at the periphery of the invasive islands of carcinoma (arrows).

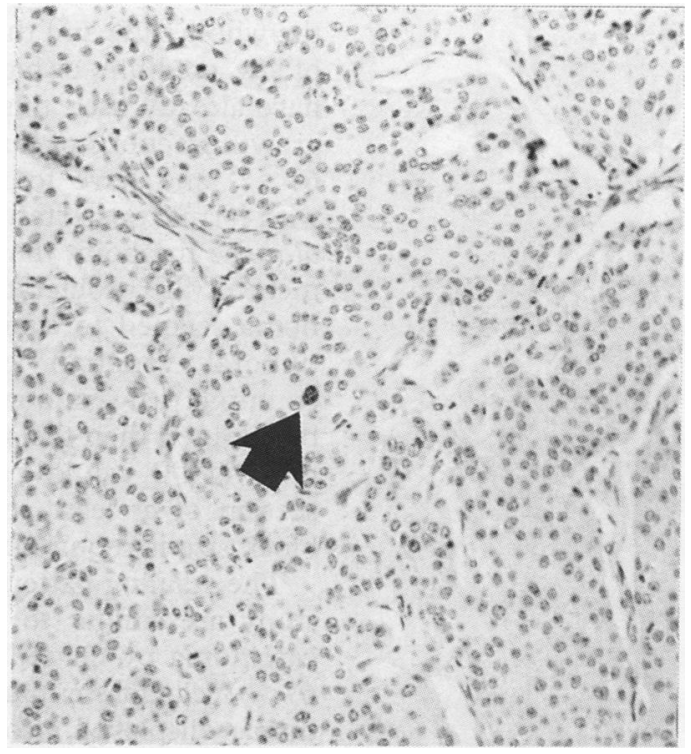

Figure 3 Section of carcinoid tumour of the lung stained with PC10 showing only occasional positive nuclei (arrow).

cores. As can be seen from table 1 and fig 1 most cases did not differ dramatically within the paired PI values. Indeed, in view of the 30 -fold difference in sample size, it is perhaps surprising that the correlation between the two techniques is so good. However, there was a striking difference of PI values within certain pairs-cases $6,7,11,12$ and 19. These cases include squamous cell carcinomas, small cell carcinomas, and adenocarcinomas. No obvious reason for such a disparity in PI values within these particular cases, other than sampling error, is apparent. One of the aims of tumour proliferation studies is to provide an accurate prognostic indicator which can be used by clinicians to assess individual patients. Because a conventional tissue block would always be used in such circumstances, the problem of possible sample size error inherent to the MTTB technique would not arise, but its use in quantitative studies is inappropriate.

This conclusion is, of course, based on the study of lung carcinomas, a group of histologically and immunocytochemically heterogeneous tumours. ${ }^{22}$ Carey et al have recently described pronounced heterogeneity of cell proliferation in non-small cell carcinomas of the lung using an antibody similar to $\mathrm{PC} 10 .^{23}$ Other tumours, such as non-Hodgkin's lymphomas, ${ }^{24}$ seminomas, ${ }^{25}$ and colorectal carcinomas, ${ }^{26}$ have been shown to be more homogenous, thereby reducing sampling error and possibly making the MTTB technique more applicable.

Several recent papers have reported the promising prognostic value of $\mathrm{PC10}$ in a number of different tumours, such as gastric carcinoma, ${ }^{27}$ gastrointestinal lymphomas, ${ }^{28}$

Table 2 Comparison of means of proliferative indices according to histological subtype

\begin{tabular}{|c|c|c|c|}
\hline Type & No of case & MTTB (\%) & Conventional (\%) \\
\hline $\begin{array}{l}\text { Carcinoid } \\
\text { Adenocarcinoma } \\
\text { Squamous } \\
\text { Small cell }\end{array}$ & $\begin{array}{l}2 \\
8 \\
5 \\
5\end{array}$ & $\begin{array}{r}2 \\
24 \\
41 \\
48\end{array}$ & $\begin{array}{r}1 \\
21 \\
36 \\
40\end{array}$ \\
\hline
\end{tabular}

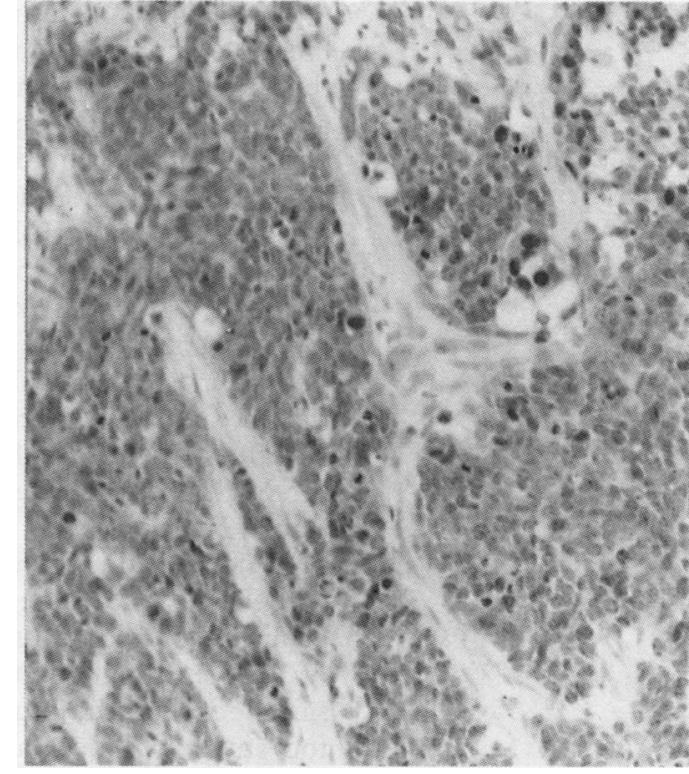

Figure 4 Section of a small cell carcinoma of the lung stained with PC10. Most tumour nuclei are positive, although some are more intensely stained than others.

and haemangiopericytomas. ${ }^{29}$ The acceptance, by general diagnostic pathologists, of an immunohistochemical technique which allows the assessment of a tumour's proliferative activity, and hence prognostic information, will depend on how "user friendly" it is. Currently, the most widely used means of estimating a tumour's growth rate by pathologists is by means of a mitotic count, a method whose accuracy and relevance to prognosis has been challenged. ${ }^{30-32}$ However, it does have the advantage that only a small number of cells need be counted, and hence persuading pathologists to change to a procedure which involves counting around 1000 cells may prove difficult. One option is the use of a semiquantitative assessment. This involves a visual inspection of the immunocytochemically stained tissue section at medium power over 
the whole slide and then deciding whether it is of low, medium, or high grade. Several authors have already used this technique for assessing growth fractions of tumours with antibody $\mathrm{Ki}$ $67^{33} 34$ and have found excellent correlation with formal quantitative counts. Indeed, Jain et al make the point that semiquantitatve assessment of the proliferation rate of gastric carcinoma seemed to avoid the problem of intratumoral variation encountered in formal counting. ${ }^{27}$ If semiquantitative assessment is to be adopted then the small tissue cores used in the MTTB would be unsuitable as a tissue section of at least conventional paraffin wax block size is required.

The staining patterns observed by us in this study are similar to those described in lung carcinoma by Gatter et al using antibody $\mathrm{Ki}$ $67 .{ }^{34}$ Well differentiated squamous cell carcinomas displayed strong staining of nuclei in those tumour cells at the periphery of invasive islands (fig 2), a pattern reported previously in cervical carcinoma ${ }^{35}$ using $\mathrm{Ki}-67$ and in verrucous carcinoma using tritiated thymidine. ${ }^{36} \mathrm{We}$ agree with the findings of Carey et al, who report a large intratumoral variation in proliferative activity within lung carcinomas. ${ }^{23}$ In the present study this was most noticeable among the group of squamous and adenocarcinomas. As one would expect, tumours which are biologically non-aggressive and are known to have a low proliferative rate, such as carcinoids, had the lowest PI values (mean of $2 \%$ and $1 \%$ using MTTB and conventional block, respectively). Those which are known to behave in a biologically high grade mannerthat is, small cell carcinomas-had the highest PI values (means of $48 \%$ and $40 \%$ ) using both the MTTB and conventional block techniques (table 2).

In conclusion, the MTTB technique seems to be a less accurate means of assessing the proliferation rate of lung tumours than the use of conventional tissue blocks because the sample size in the multitumour tissue block is too small to reflect accurately each tumour's overall proliferation rate. It is suggested that the MTTB technique be restricted to qualitative studies for which it was originally intended or perhaps quantitative studies using tumours with little intratumoral variation.

We thank Mr Andrew Heryet for his excellent technica assistance in cutting and immunostaining the tissue sections.

1 Battifora H. Methods in laboratory investigation. The Multitumor (sausage) tissue block; novel method for Immunohistochemical antibody testing. Lab Invest 1986;55:244-8.

2 Wan W-H, Fortuna MB, Furmanski P. A rapid and efficient method for testing immunohistochemical reactivity of mothod for testing immunohistochemical reactivity of monoclonal antibodies against multiple tissue sam

3 Rowden G, Fraser RB. Preparation of "Histocomposites" for direct immunohistological screening of monoclonal for direct immunohistological screening

4 Parums DV, Cordell JC, Micklem K, Heryet AR, Gatter KC, Mason DY. JC70: a new monoclonal antibody that detects vascular endothelium associated antigen on rou tinely processed tissue sections. F Clin Pathol 1990 43:752-7.

5 Hall PA, Levison DA, Woods AL, et al. Proliferating cell nuclear antigen (PCNA) immunolocalization in paraffin sections: an index of cell proliferation with evidence of deregulated expression in some neoplasms. F Pathol 1990;162:285-94

6 Quinn CM, Wright NA. The clinical assessment of proliferation and growth in human tumours: evaluation of 1990;160:93-102.

7 Rosai J. Respiratory tract. In: Ackerman's surgical pathology 7th Edn. St Louis: CV Mosby, 1989:295-305.

8 Gatter KC, Falini B, Mason DY. The use of monoclonal antibodies in histopathological diagnosis. Rec Adv Histopathol 1984;12:35-67.

9 Siegel S. Wilcoxon matched-pairs signed-ranks test. Nonparametric statistics for the behavioural sciences. International Student Edition. Tokyo: McGraw-Hill-Kogakusha, 1956:75-83.

10 Chauvel P, Courdi A, Gioanni J, Vallicioni J, Santini J, Demard $F$. The labelling index: a prognostic factor in head and neck carcinoma. Radiother Oncol 1989;14: 231-7.

11 Costa A, Banadonna G, Villa E, Valagussa P, Silvestrini R. Labelling index as a prognostic marker in non-Hodgkin's lymphoma. भNCI 1981;66:1-5.

12 Meyer JS. Cell kinetic measurements of human tumors. Hum Pathol 1982;13:874-7.

13 Strang P, Eklund G, Stendahl U, Frankendal B. S-phase rate as a predictor of early recurrences in carcinoma of the uterine cervix. Anticancer Res 1987;7:807-10.

14 Tubiana M, Courdi A. Cell proliferation kinetics in human solid tumours: relation to probability of metastatic dissemination and long-term survival. Radiother Oncol 1989; 15:1-18.

15 Brown DC, Gatter KC. Monoclonal antibody Ki-67: its use in histopathology. Histopathology 1990;17:489-503.

16 Hall PA, Richards MA, Gregory WM, d'Ardenne AJ, Lister TA, Stansfeld AG. The prognostic value of Ki67 immunostaining in non-Hodgkin's lymphoma. $\mathcal{f}$ Pathol 1988; 154:223-35.

17 Ueda T, Aozasa K, Tsujimoto $M$, et al. Prognostic significance of $\mathrm{Kj}-67$ reactivity in soft tissue sarcomas. Cancer 1989;63:1607-11.

18 Bouzubar N, Walker KJ, Griffiths K, et al. Ki-67 immunostaining in primary breast cancer: pathological clinical associations. Br 7 Cancer 1989;59:943-7.

19 Ostmeier $\mathrm{H}$, Suter $\mathrm{L}$. The $\mathrm{Ki}-67$ antigen in primary human melanomas-its relationship to mitotic rate and tumor thickness and its stability. Arch Dermatol Res 1989;281: 173-7.

20 Lee SA, Hurwitz J. Mechanism of elongation of primed DNA by DNA polymerase delta, proliferating cell antigen, and activator 1. Proc Natl Acad Sci USA 1990; 87:5672-6.

21 Waseem N, Lane DP. Monoclonal antibody analysis of the proliferating cell nuclear antigen (PCNA) Structural conservation and the detection of a nucleolar form. $\mathcal{F}$ Cell Sci 1990;96:121-9.

22 Gatter KC, Dunnill MS, Heryet A, Mason DY. Human lung tumours: does intermediate filament co-expression correlate with other morphological or immunocytochemical features? Histopathology 1987;11:705-14.

23 Carey FA, Fabbroni G, Lamb D. Assessment of heterogeneity of cell proliferation in lung cancer using a monoclonal ity of cell proliferation in lung cancer using a monoclonal
antibody to proliferating cell nuclear antigen. $₹$ Pathol antibody to pro

24 Brown DC, Gatter KC, Mason DY. Proliferation in nonHodgkin's lymphoma: a comparison of $\mathrm{Ki}-67$ staining on fine needle aspiration and cryostat sections. $\mathcal{f}$ Clin Pathol 1990;43:325-8.

25 Due W, Dieckmann K-P, Loy V. Immunohistological determination of proliferative activity in seminomas. $f$ Clin Pathol 1988;41:304-7.

26 Porschen R, Lohe B, Klaus-Jurgen H, Borchard F. Assessment of cell proliferation in colorectal carcinomas using the monoclonal antibody Ki-67. Cancer 1989;64: 2501-5.

27 Jain S, Filipe MI, Hall PA, Waseem N, Lane DP, Levison DA. Prognostic value of proliferating cell nuclear antigen in gastric carcinoma. $f$ Clin Pathol 1991;44:655-9.

28 Woods AL, Hanby AM, Hall P, Waseem N, Lane DP, Levison DA. The prognostic value of PCNA (proliferating cell nuclear antigen) immunostaining in gastro-intestinal lymphomas. F Pathol 1990;161:342A.

29 Yu C, Hall PA, Fletcher CDM, et al. Immunohistochemical staining with a monoclonal antibody to proliferating cell nuclear antigen may be a good indicator of prognosis in haemangiopericytomas. F Pathol 1990;161:342A.

30 Donhuijsen K. Mitosis counts: reproducibility and significance in grading malignancy. Hum Pathol 1986;17: $1122-5$.

31 Silverberg SG. Reproducibility of the mitosis count in the histologic diagnosis of smooth muscle tumours of the uterus. Hum Pathol 1976;7:451-4.

32 Sadler DW, Coghill SB. Histopathologists, malignancies and undefined high-power fields. Lancet 1989;i:785-6.

33 Weiss LM, Strickler JG, Medeiros LJ, Gerdes J, Stein H, Warnke RA. Proliferative rates of non-Hodgkin's lymphomas as ass

34 Gatter KC, Dunnill MS, Gerdes J, Stein H, Mason DY New approach to assessing lung tumours in man. $f$ Clin Pathol 1986;39:590-3.

35 Brown DC, Cole D, Gatter KC, Mason DY. Carcinoma of the cervix uteri: an assessment of tumour proliferation using the monoclonal antibody $\mathrm{Ki} 67 . \mathrm{Br} F$ Cancer 1988;57:178-81.

36 Prioleau PG, Santa Cruz DJ, Meyer JS, Bauer WC Verrucous carcinoma. A light and electronic microscopic autoradiographic, and immunofluorescence study. Cancer 1980;45:2849-57. 